\title{
The Wilson family farm
}

\author{
Derek Murray
}

This manuscript was prepared for HIST*4620 Canadian Rural History under the supervision of Prof. Douglas McCalla, Department of History, College of Arts.

\begin{abstract}
Tradition versus modernity-and the spaces in between-is a major theme not only in the study, but also in the popular image of Canadian rural history. Our rural ancestors are often portrayed as self-sufficient, independent units. Closed off from market economies and providing everything they need on their own, they are models of an ideal, traditional and long-forgotten way of life. On the other hand, it is also possible that these people were market-oriented to the extent of solely producing staple crops for sale on lucrative foreign markets. I have had the opportunity to examine a rich historical source from the mid-nineteenth-century. The account book from the farm of James Wilson of North Dumfries, Ontario from 1866 to 1869 is one of many sources in the University of Guelph's rural history archive that offers researchers a provocative glimpse of life in Canada in the past. The majority of this paper is devoted to the analysis of James Wilson's account book itself and the world it reveals. It is in these spaces-in the worlds of which the Wilson farm is one example - that tradition and modernity become secondary to the mediating and motivating force of the needs of the individual, the family or the group. In the mid-nineteenth century the family was the main unit of economic, social and political agency for many people. James Wilson and his family were involved in local affairs at every level: economic, social, cultural, religious, political, etc. The world in which this family lived contained both traditional and modern elements. It was not the case that they blindly followed the traditions of the past, nor was it the case that they put all their faith in free-market economics or the values of modernity. The Wilson family lived between two extremes, with the needs and desires of the family being always paramount.
\end{abstract}

$\mathrm{T}$ radition versus modernity - and the spaces in betweenis a major theme not only in the study, but also in the popular image of Canadian rural history. Our rural ancestors are often portrayed as self-sufficient, independent units. Closed off from market economies and providing everything they need on their own, they are models of an ideal, traditional and long-forgotten way of life. They live in isolated worlds with only their family members and immediate neighbours for company. On the other hand, it is also possible that these people were market-oriented to the extent of solely producing staple crops for sale on lucrative foreign markets. They sought profit by whatever means and at whatever cost, employing all the available strategies of modern economics. While the above description oversimplifies the issue, it serves to lay out the broad theme of this paper. In my research this theme is a guiding motif and presently sets the stage for what is to come.

Did our rural ancestors really live at one of these two extremes? Or were they somewhere in the expansive middle ground: a people who created their own 'modern' world, interacting within larger worlds (economic, social, political, cultural), albeit retaining a firm and confident identity rooted in 'traditional' values and practices? In seeking out the answer to this question, I have had the opportunity to examine a rich historical source from the mid-nineteenthcentury. The account book from the farm of James Wilson of North Dumfries, Ontario from 1866 to 1869 is one of many sources in the University of Guelph's rural history archive that offers researchers a provocative glimpse of life in Canada in the past. The challenge for historians is to make sense of all these different lives and perspectives, and in so doing, produce a coherent version of history that respects this diversity, while also keeping in mind the major themes and developments in Canadian history (which are constantly being redefined and reshaping our vision of the past). In the coming pages, I will present the story of the Wilson family farm as it has been revealed to me through this account book, through course readings and discussions and through my own independent research. ${ }^{1}$ In telling the story of this one farm, in conjunction with other stories being told by other researchers, we will get a better idea of the kinds of worlds in which our rural ancestors lived. First, I will look more closely at the general theme of tradition and modernity. Secondly, I will examine the importance of family in general and as an economic, social, political and cultural unit. Finally, the majority of this paper is devoted to the analysis of James Wilson's account book itself and the world it reveals. 


\section{Part I: Tradition and MOdernity aS CONCEPTS IN RURAL HISTORY}

Tradition versus modernity. When expressed as competitive forces, they are incompatible. An examination of what they entail, however, may show us that they are not so far apart in real, lived experience. We use them so often without reflecting on their deep history and evolution that we may lose sight of their intersection. Tradition can simply mean adhering to particular practices that have been passed down through successive generations. These could be certain values or value systems, farming practices, social organization and the like. Modernity, conversely, refers to something present, something new and (supposedly) better. Embracing modernity means accepting that the present has somehow broken from the past and that there is a fundamental difference between the social and cultural practices of today and yesterday. ${ }^{2}$ In light of these definitions, tradition and modernity seem dichotomous, unable to co-exist in any meaningful way- as one is the contradiction of the other. However, this is not a necessary conclusion. It is quite possible to embrace both while living in between the extremes.

Gerald L. Pocius' study of the small fishing community of Calvert, Newfoundland, shows us how attempts at the commodification of 'heritage' and 'culture' cause one to rethink notions such as 'roots'. ${ }^{3}$ Are cultural traditions something that can be consumed by tourists? While these variations of "artefacts" can be seen as representations of something worthy-i.e. the traditions of old-the introduction of new innovations in technology and cultural media (e.g. radio, television) are often viewed as detrimental to traditional customs and practices. "Indeed, rarely is anything essentially recent and modern seen in a positive light. Notions about what should be objectified as traditional often are promoted by middle-aged and older intellectuals who may be traditionalizing the images of their own childhood as an ideal model, so that nothing new is appealing." " Pocius' study of Calvert addresses this dichotomy between new and old, between tradition and modernity. Emphasis is placed not on artifacts, but on the spaces in which people live and operate. "Calvert space is constructed so that socializing takes precedence over most everything else, work often requires the sharing of natural resources, and time not working is devoted to the family visit, the community Sunday mass, or the school concert, and rarely to individualistic leisure." ${ }^{, 5}$ These spaces constitute the vernacular worlds in which people live. The essence of tradition exists in these spaces: it is in lived experience and cannot be captured in objects or representations. In other words, "Tradition is not the unwavering reproduction of the past so often called for; instead static replication is tradition's grave marker." The loss of tradition comes with the loss of these essential social interactions and with the commodification of tradition itself.

Are tradition and modernity completely incompatible? It is often asserted that this is so. Consider the attempts of the Makah, natives of Canada's northwest coast, to fashion a 'modern' identity in the late-nineteenth-century while staying true to traditional values: "Dominant society's refusal to acknowledge the possibility of fusing 'traditional' and 'modern,' 'uncivilized' and 'civilized,' 'Indian' and 'White' made [this task] all the more difficult." Modernity, however, does not necessarily mean the loss of tradition. It does mean the rational acknowledgment of something new as being perhaps better suited to a task or function. If one has a large and successful farm, it is simply practical to adopt the tractor as an essential component of this growth and success. To be modern means to embrace the present and the positives that it has to offer and while this means accepting change, it does not mean forgetting the past or abandoning values. In participating in a traditional whale hunt using modern technology, the Makah “... created authentic meaning by reinventing old customs anew." "They knew that, as twentieth-century Makah, they could use modern tools to honour their past and their ancestors without sacrificing their integrity or identity as Makah." not defined by the prescribed limits of outsiders. It is in these spaces-in the worlds of which the Wilson farm is one example-that tradition and modernity become secondary to the mediating and motivating force of the needs of the individual, the family or the group.

\section{Part II: The Value OF Family}

What was the importance of family for our rural Canadian ancestors? In the mid-nineteenth century the family was the main unit of economic, social and political agency for many people. Anything that was done, was done so in the context of what was in the best interests of the family before the individual. The family is also the conduit through which traditions are upheld and in which modernity is embraced. However, social reformers of the early twentieth century “...saw the people of the countryside as an obstacle to change-particularly the farmers hostile to state attempts at modernization." ${ }^{10}$ Were farmers and their families resisting modernization in hopes of maintaining an ideal traditional lifestyle? Or were there perhaps other factors at work? What we have shown so far is that there are always forces of tradition and modernity at work, but these alone cannot explain the decisions and actions of farmers.

Our rural ancestors lived in complex and dynamic worlds involving many contingencies, trends and factors beyond their control. The family acted as overriding project focusing the energies of households in a certain direction. The resources and opportunities available to the farmer, in 


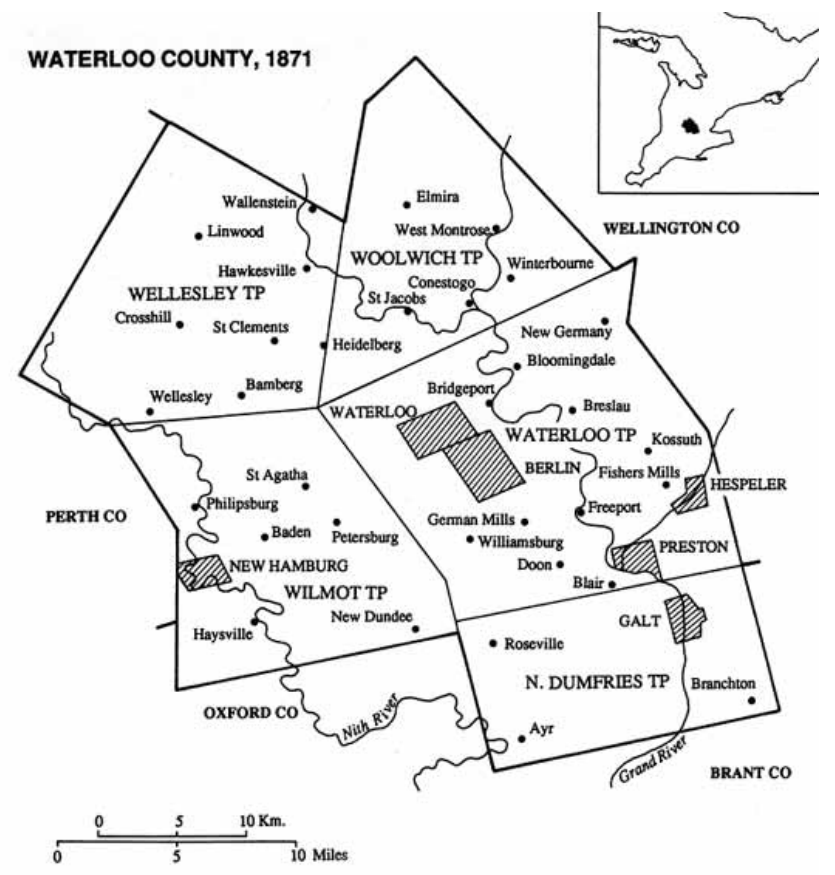

combination with the entrepreneurship, skill and determination of his family, under the guise of its success and preservation and within the economic, social and political circumstances of the day constitute the myriad issues and factors that make up the worlds in which our rural ancestors lived. Allan Bogue's account of life on The Farm on the North Talbot Road sheds some light on this complexity:

The history of the farm on the North Talbot Road was not a chronicle of a dominant father or mother or of the conflict between them; it was a family story in which children played significant roles in shaping outcomes, and influences other than rational economic decision making helped to explain the conclusion. ${ }^{11}$

The success of the farm was truly a family effort. It was strong families that survived through the harshest circumstances and thrived in the periods of prosperity. There were entrepreneurs in the nineteenth century who recognized this and actively recruited families to come and settle. One of these was William Dickson, the lawyer and land speculator who initiated and oversaw the settlement of the township of North Dumfries, the southernmost township in Waterloo County. He bought the land in 1811 and had it surveyed in 1816 with settlement beginning soon thereafter. ${ }^{12}$ He actively sought out settlers from Scotland and treated them paternally, settling them on their land and providing them with stock, implements, provisions and cash advances. ${ }^{13}$ Dickson and his colleagues founded a thriving settlement and turned over its administration to his sons in $1837 .{ }^{14}$ In 1839 , at an address to the attendees of his $70^{\text {th }}$ birthday party, he had this to say about the settlement he initiated:

\begin{abstract}
When a newcomer with a family presented himself, I did not make the enquiry so much for money as I did to ascertain if the party was honest, industrious and laborious. Assistance in cattle, provisions and other necessities was given and under a personal supervision the township has become the residence and abode of a happy and wealthy population. ${ }^{15}$
\end{abstract}

Dickson was looking for a particular kind of settler: one that came from a proud tradition, who could break the land, make it productive and establish a strong and thriving community that would last for generations. He saw the importance of strong families in building strong communities. The Wilson family was one of these. Let us now turn our attention to this family and its story.

\section{PART III: The Wilson FAMily FARM}

One group of settlers who came from Scotland in 1834 included James Wilson's father, Robert Lundy Wilson. ${ }^{16}$ Robert was not one of the most prominent members of the community, but he was involved at a moderately high level. He was a municipal council member from 1853 to 1855 and was Deputy Reeve in $1856 .^{17}$ In 1851 he established the family farm at Concession 10, Lot 25, where his descendents would continue to reside for over a century. It was not long after this that Robert passed the farm over to his son James, who took up the responsibilities of the farm, while at the same time taking an active interest in local affairs. James Wilson, aside from being a successful farmer, was township Treasurer for 1868-76, Assessor in 1871 and in 1852-53 he was Commissioner in charge of "....improving the road from the Galt corporation to Cedar Creek, on the line of road between the $11^{\text {th }}$ and $12^{\text {th }}$ Concessions..." ${ }^{18}$ In 1967, the Junior Farmers of Ontario recognized the Wilson farm as a 'Century Farm', one that had been in the hands of the same family for one hundred years or more. ${ }^{19}$ The fact that there were thirteen farms in North Dumfries which received this distinction says something not only about the fertility of the land, but also about the families that settled and farmed there. In a sense, you could say that the project William Dickson initiated was a success because of the success of such families. North Dumfries is today still largely a farming community, although the city of Cambridge and the town of Galt continue to expand nearby. This serves as enough introduction and context-now on to the account book itself. What kind of story does this book tell us? What kind of world does it reveal? I will divide my analysis into two broad sections: economic environment and social environment. This division merely provides a framework for analysis, since the various environments overlap within one world. We will deal first with the factors of the social environment and 


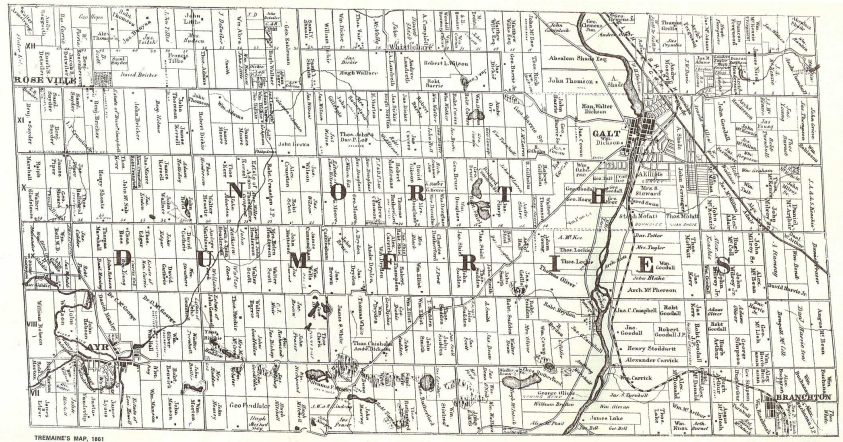

North Dumfries in 1861, in Andrew W. Taylor, Our Todays and Yesterdays, 315.

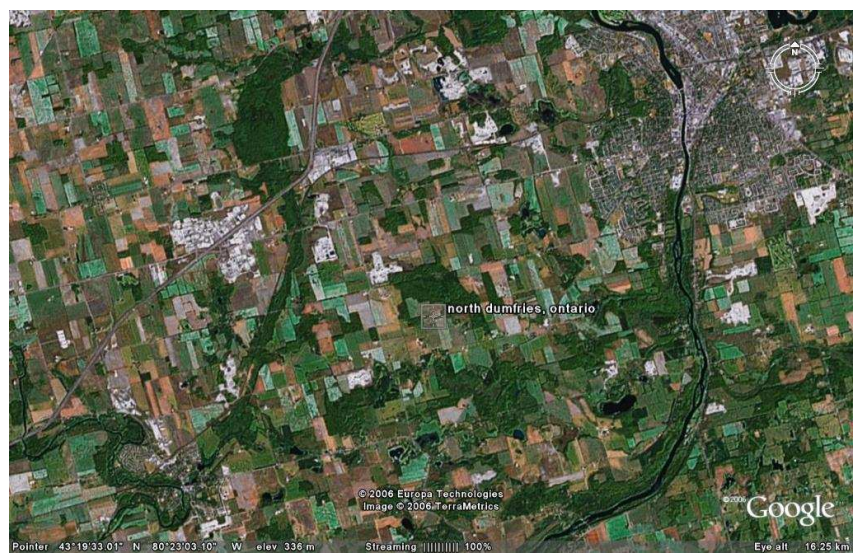

North Dumfries Today. Google Earth, Europa Technologies, 2006.

secondly with those factors associated with the economic environment.

\section{Social Environment}

By social environment I simply mean those relationships which constitute social organization and interaction. Religion, politics and education come under this heading. The values of family and community go hand in hand. The value of social interaction and organization for farm families in the nineteenth century was huge. They were not isolated or self-sufficient, but were involved in sophisticated social and economic relationships of inter-dependency. James Wilson's account book reveals some interesting facets of life on the farm in 1866-69 which can fall under this general theme. A substantial portion of entries in the expense column of the account could be called expenses on education. James was well read, with some examples of publications being: numerous newspapers (e.g. Montreal Gazette, Globe), Canadian Almanac, American Agriculturalist, Canada Farmer, Home Mission and Memoirs of Prince Albert. There are also many purchases of items such as pens, ink, workbooks and other stationery. James was actively looking to better his family's position through education for himself and his children. Through publications such as these he could keep up to date on such things as political events and new farm practices. Another example of his interest in political affairs is the purchase of a photo of 'McGee' for ten cents on 25 April 1868. This is surely a reference to Thomas D'Arcy McGee, the notable journalist, poet and politician who was one of the fathers of Confederation. He was assassinated in 1868 on the $7^{\text {th }}$ of April. ${ }^{20}$ This shows not only an interest in current affairs, it also gives us a possible indication of James' political ideology.

As well as being politically aware, James was active in the social life of his community. He was a member of the local Presbyterian Church. Numerous and regular entries are given to the purchase of religious publications (e.g. 'Good Words magazine'), as well as church seat rentals and school taxes (e.g. Apr/67, Dec/67). It is reasonable to infer from this that religion and education played a major role in shaping the world of the Wilson family farm. While only a very small portion of their income was spent on leisure, James and his wife did attend several charity concerts and community events over this period (e.g. Feb/66, Mar/67). This evidence of the importance of community is reinforced by other farm families whose experiences have been documented. The diaries of Rebecca Ells and Ephraim Cressman show us through two distinct stories that the success of the family was at least in part dependent on the social relationships of community through venues such as religion, the neighbourhood and the local economy. For Ells, "In the absence of her husband, the close network of family and friends sustained [her] through her difficulties and triumphs." 21 As well as this "... a strong Baptist faith offered consolation...[and]...a telephone, installed in 1904, was considered 'a great invention' by Rebecca, who was now able to keep in closer touch with her kin and community.",22 Though Ells valued her heritage, there was at the same time no harm in embracing a new invention, namely the telephone, which rather than replacing traditional means of communication, served to expand the means through which traditional values and ideas could be communicated and transmitted. Cressman was actively involved in community life as well. He interacted and did business with his neighbours and he was involved in his church and other organizations. $^{23}$ These types of social relationships were important not only for community building, but for the preservation of the family itself.

\section{Economic Environment}

In addition to the relationships of the social environment mentioned above, James Wilson and his family were involved in many local and regional economic relationships. These, in addition to the technology used on the farm and the types of products produced and consumed give us a better idea of the kind of world in which the family lived. Let us first look at technology used on the farm. The period 1866- 
69 was before the tractor came into common use. The Wilson farm used both man power and animal power. There is ample evidence of this in the account book. The following list of purchases illustrates this:

- Jan/66, 'braid for horse blankets'

- Apr/66, 'plough lines', 'plough beam and stilt', 'slip for plough'

- Aug/66, 'new plough'

- May/67, 'yoke of oxen, \$135'

- $\quad$ Dec/67, '1 yoke oxen, 1 cow, 1 steer, \$115' (sold)

They not only used horses and oxen for draft power, but bought and sold livestock as well. In addition, the horse was used for transportation off the farm. The following list shows some examples of expenses related to this use of the horse:

- Jan/68, 'hay for horse at Guelph, 12.5ф'

- Jan/68, 'hay for horse at Elora, 10ф'

- Sep/68, 'Democrat Buggy, \$96'

- $\quad$ Dec/67, 'R. Vair, new sleigh, \$12'

Other examples of the use of technology on the farm are:

- Jul/66, 'powder and shot, \$6'

- Nov/66, 'pistol and 2 boxes of cartridges, $\$ 14.25$ '

- Oct/67, 'fixing pulley of threshing machine, $90 \varnothing$ '

- Nov/67, 'two reaping hooks, 75ф'

- Jun/68, 'repairing mowing machine', 'scythe'

- Jul/68, 'reaping machine fixed, $\$ 1$ '

- Dec/68, 'gumming cross-cut saw, $\$ 1$ '

- Feb/69. 'turnip cutter, $\$ 10.75$ '

- Apr/69, 'grain drill, \$32.5'

The family was wealthy enough that they could afford their own equipment. In this sense the farm remained relatively independent. Does this mean it was self-sufficient? Another way of exploring the economic environment is to look at the different accounts James had with his neighbours. The farm was successful enough that James did not have to spend a lot of time working off the farm. In 1866 and 1867, the farm was doing well and he was able to hire extra help during harvest season: Jul/68, 'harvest wages $3 \mathrm{men} / 1$ day binding, $\$ 6$ ', '1 man/3 days hauling, \$6'. James also hired local people for jobs such as weaving and mending boots and shoes, as well as frequently travelling to the market in Galt. In 1868 and 1869 sales of wheat and other produce on the farm dropped off and James supplemented the farm income with off farm work. He was paid by Theodore Goodfellow to do some threshing, underbrushing and picking stones. It is interesting to note that James also hired Goodfellow to do some of the same jobs for him. This was not the only reciprocal economic relationship that James was involved in. In November 1868, James took two cows to John Brown's
Table 1 - Revenue by Product, \$

$\begin{array}{lccccc}\text { Product } & \mathbf{1 8 6 6} & \mathbf{1 8 6 7} & \mathbf{1 8 6 8} & \mathbf{1 8 6 9} & \text { \% of Revenue } \\ \text { Livestock } & 135 & 233 & & 86 & 22 \\ \text { Apples } & 14 & 21 & & & 2 \\ \text { Wheat } & 118 & 376 & 261 & 66 & 40 \\ \text { Barley } & 52 & 50 & 64 & & 8 \\ \text { Potatoes } & 2 & 59 & 7 & & 3 \\ \text { Meat Products } & & & & 40 & 2 \\ \text { Forest Products } & 24 & & 69 & 180 & 13 \\ \text { Butter } & 46 & 8 & 61 & & 5 \\ \text { Eggs } & & & 16 & & 1 \\ \text { Wool } & & & 25 & & 1 \\ \text { Labour } & 1 & & 20 & 34 & 3 \\ \text { Other } & 390 & 747 & 527 & 406 & 100 \\ \text { Total Revenue } & & & & & \end{array}$

bull and in January the next year, John Brown bought 107lbs. of beef. These relationships indicate a willingness to cater to local markets as opposed to larger foreign ones.

The case of the Belleview Farm in W.H. Graham's Greenbank: Country Matters in $19^{\text {th }}$ Century Ontario offers a view of the importance of these types of relationships both in their social context and in an economic context. Graham argues that the risks involved in catering to international markets was too much for the average farmer and that it was desirable for farmers to diversify and to strengthen local markets. ${ }^{24}$ In the 1860 s the provincial Board of Agriculture and the Arts was pushing the expansion of markets and holding regular fairs for farmers to showcase their products. $^{25}$ Marvin McInnis argues that statistical evidence for the late nineteenth century shows that the transformation of Canadian agriculture was a drawn out and complicated process with the shift from wheat to mixed farming happening before 1870 and that "...The role of export markets has probably been overemphasized." ${ }^{26}$ The Wilson family farm was not self-sufficient. At the same time it was not a farm that was devoted to staple crops or quick profits. They sold their products in local markets, to local people and bought from these same people. What was produced on this farm says something about the type of farm it was and the people who ran it. The following is a complete list of the different items that were produced on the farm for sale at market: livestock, apples, potatoes, and forest products, several kinds of wheat, barley, meat products, butter, eggs and wool. Table 1 presents this in data form. While wheat represents $40 \%$ of farm income over the four year period, it is not the case that the farm was dependent on wheat. Animal and forest products provided substantial income, while products such as eggs and butter provided regular spending money for the household. Aside from what he could achieve on his own, James also relied on others. James was paying interest on a mortgage to his father of $\$ 136$ a year (e.g. 11/Apr/68). It was James' father who gave him his start in farming and James was in debt to him.

A separate account details the sale of butter and eggs, with purchases of things such as groceries, tea and cloth recorded alongside. What else was consumed on this farm? What kind of shopping did the Wilson family do? Items mentioned in 
the diary include: coffee, sugar, beef, and other food stuffs as well as cotton, and other materials for clothing. They didn't shop if they could make it themselves, but there were many things that it was simply more practical to buy. Whereas they did make their own clothes to a large extent, they never made the fabrics that went into the clothes. They were one stop in a commodity chain, not an isolated economy in itself. This reflects the importance of the relation between family and neighbourhood. "In the nineteenth century, neighbourhood was not just the people who lived near you but the basis for economic activity, social support, and the organization of day-to-day living."27 While Catharine Wilson's argument pertains specifically to the role of the work bee to rural economies, it identifies the relationship between family, community and economy that I have been trying to elucidate in this paper. "Thus the bee helped to create a structural and cognitive order in the neighbourhood. Like the potlatch, it was not only an economic and social exchange but also a process through which shared values and a collective identity were created and communicated." ${ }^{, 2}$ This structural order is an integral component in the world that is the Wilson family farm.

\section{CONCLUSION}

The world of the Wilson family farm was complex, dynamic and full of diverse relationships. These relationships constituted the world in which the Wilsons lived. How did James make sense of all these different relationships himself? This is something we may never know. We can, however, make conclusions based on what he chose to write down and what we know about his world. Indeed, there were forces of tradition which undoubtedly had their impact on the lives of rural populations, but this does not mean that such people were backward or isolated. James Wilson and his family were involved in local affairs at every level: economic, social, cultural, religious, political, etc. They were involved in many family, community and economic relationships which were overlapping and difficult to disentangle. The world in which this family lived contained both traditional and modern elements. There was no revolutionary change in the way they did business, but rather a continuity of decisions whose aim was the success and preservation of the family unit. It was not the case that they blindly followed the traditions of the past, nor was it the case that they put all their faith in free-market economics or the values of modernity. The Wilson family lived between two extremes, with the needs and desires of the family being always paramount.

\section{ENDNOTES}

${ }^{1}$ This paper was originally written as the final assignment for HIST4620, Canadian Rural History, at the University of Guelph, Fall 2006, under Professor Douglas McCalla.

2 Richard Hooker, Washington State University, "Modernity," World Cultures: General Glossary, 14 July 1999 ,

<http://www.wsu.edu/ dee/GLOSSARY/MODERN.HTM> (8 February 2008).

${ }^{3}$ Gerald L. Pocius, A Place to Belong: Community Order and Everyday Space in Calvert Newfoundland (Montreal and Kingston: McGill-Queen's University Press, 2000), xii.

${ }^{4}$ Pocius, A Place to Belong, 275.

${ }^{5}$ Ibid., 272.

${ }^{6}$ Paige Raibmon, Authentic Indians: Episodes of Encounter from the Late-Nineteenth-Century Northwest Coast (Durham and London: Duke University Press, 2005), 13.

${ }^{7}$ Raibmon, Authentic Indians, 201.

${ }^{8}$ Ibid., 13.

${ }^{9}$ Ibid.

10 Ambrose and Kechnie, "Social Control or Social Feminism?: Two Views of the Ontario Women's Institutes," Agricultural History 73 (1999): 227.

11 Allan G. Bogue, The Farm on the North Talbot Road (Lincoln: University of Nebraska Press, 2001), xii.

12 Library and Archives Canada, "Dickson, William," Dictionary of Canadian Biography Online, 2000, <http://www.biographi.ca/EN/ShowBio.asp?BioId=37478\&q uery=william\%20AND\%20dickson>

(15 November 2006).

13 Ibid.

14 Ibid.

15 Andrew W. Taylor, Our Todays and Yesterdays (North Dumfries and Ayr Centennial Committee, 1970), 39-40.

16 Taylor, Our Todays and Yesterdays, 38.

${ }^{17}$ Ibid., 334.

18 Ibid., 47.

${ }^{19}$ Ibid., 290.

20 Library and Archives Canada. "McGee, Thomas D'," Dictionary of Canadian Biography Online, 2000, <http://www.biographi.ca/EN/ShowBio.asp?BioId=38705\&q uery=thomas $\% 20$ AND $\% 20 \mathrm{mcgee}>$

(15 November 2006).

21 "Diary of Rebecca Chase Kinsman Ells," in Margaret Conrad, Toni Laidlaw and Donna Smyth, eds., No Place Like Home: Diaries of Nova Scotia Women 1771-1938 (Halifax: Formac, 1988), 206. 
22 Ibid.

23 "Diary of Ephraim Cressman," in Royden Loewen, ed., From the Inside Out: The Rural Worlds of Mennonite Diarists, 1863 to 1929 (Winnipeg: University of Manitoba Press, 1999), 150.

24 W.H. Graham, Greenbank: Country Matters in $19^{\text {th }}$ Century Ontario (Peterborough: Broadview Press, 1988), 217.

${ }^{25}$ Graham, Greenbank, 222.

26 Marvin McInnis, "The Changing Structure of Canadian Agriculture, 1867-1897," The Journal of Economic History 42, no. 1 (March 1982): 192.

27 Catharine A. Wilson, "Reciprocal Work Bees and the Meaning of Neighbourhood," Canadian Historical Review 82, no. 3 (September 2001): 433.

${ }^{28}$ Ibid.

\section{REFERENCES}

Ambrose, Linda M. and Margaret Kechnie. "Social Control or Social Feminism?: Two Views of the Ontario Women's Institutes." Agricultural History 73 (1999): 222-37.

Ankli, Robert E and Millar, Wendy. "Ontario Agriculture in Transition: The Switch from Wheat to Cheese." The Journal of Economic History 42, no. 1 (March 1982): 207215.

Bogue, Allan G. The Farm on the North Talbot Road. Lincoln: University of Nebraska Press, 2001.

Conrad, Margaret, Toni Laidlaw and Donna Smyth, eds. No Place Like Home: Diaries of Nova Scotia Women 17711938. Halifax: Formac, 1988.
Darroch, Gordon and Lee Soltow. Poverty and Inequality in Victorian Ontario: Structural Patterns and Cultural Communities in the 1871 Census. Toronto: University of Toronto Press, 1994.

Graham, W.H. Greenbank: Country Matters in $19^{\text {th }}$ Century Ontario. Peterborough: Broadview Press, 1988.

Loewen, Royden, ed. From the Inside Out: The Rural Worlds of Mennonite Diarists, 1863 to 1929. Winnipeg: University of Manitoba Press, 1999.

McCalla, Douglas. "Rural Upper Canadians go shopping: Seeing our ancestors as modern," Lecture Presented to CRC Lecture Series, University of Guelph, 10 February 2006: http://www.uoguelph.ca/ruralhistory/research/ mccalla/dMcCallaRuralShoppers10feb06.pdf.

McInnis, Marvin. "The Changing Structure of Canadian Agriculture, 1867-1897," The Journal of Economic History 42, no. 1 (March 1982): 191-198.

McInnis, Marvin. "Marketable Surpluses in Ontario Farming, 1860," Social Science History 8, no. 4 (Fall 1984): 395424.

Pocius, Gerald L. A Place to Belong: Community Order and Everyday Space in Calvert Newfoundland. Montreal and Kingston: McGill-Queen's University Press, 2000.

Raibmon, Paige. Authentic Indians: Episodes of Encounter from the Late-Nineteenth Cenutury Northwest Coast. Durham and London: Duke University Press, 2005.

Taylor, Andrew W. Our Todays and Yesterdays. North Dumfries and Ayr Centennial Committee, 1970.

Wilson, Catharine Anne. "Reciprocal Work Bees and the Meaning of Neighbourhood," Canadian Historical Review 82, no. 3 (September 2001): 431-64. 